\title{
Computational fluid dynamics analysis and experimental validation of solar panel cleaning mechanism
}

\author{
Susheel Reddy Aligireddy ${ }^{1}$, Deepali Atheaya ${ }^{2}$, Sai Manoj Katakam ${ }^{3}$, Yash Guptaa ${ }^{4}$, \\ Abhishek Mishra ${ }^{5}$ \\ Department of Mechanical and Aerospace Engineering, Bennett University, \\ TechZone-II, Greater Noida, UP, 201310, India \\ ${ }^{1}$ Corresponding author \\ E-mail: ${ }^{1}$ susheelreddyaligireddy@gmail.com, ${ }^{2}$ datheaya@gmail.com, ${ }^{3}$ katakamsaimanoj9@gmail.com, \\ 4yashguptaa11@gmail.com, ${ }^{5}$ abmi9119@gmail.com
}

Received 31 October 2019; accepted 12 November 2019 DOI https://doi.org/10.21595/vp.2019.21147

Check for updates

Copyright $(C 2019$ Susheel Reddy, et al. This is an open access article distributed under the Creative Commons Attribution License, which permits unrestricted use, distribution, and reproduction in any medium, provided the original work is properly cited.

\begin{abstract}
Solar energy is one of the widely used non-conventional form of energy. photo voltaic panels generate electricity and heat by absorbing solar irradiation. The performance of solar panels depends on several factors like dust accumulation on the surface, solar cell temperature, angle of inclination etc., To perform the cleaning action efficiently a semi-automatic cleaning mechanism has been designed and fabricated. The designed experimental setup consists of several nozzles attached on top of the solar panels and water is supplied to each nozzle using a Poly Vinyl Chloride (PVC) pipe frame connected to an AC motor operated with a time switch. Water flows on the surface of photo voltaic module, thus heat exchange takes place. One dimensional heat transfer analysis is performed and the results are compared to the experimental results for validation. The experiments were conducted at Bennett University, Greater Noida dated 9 October to 16 October. An increase in efficiency by $1.28 \%$ to $2.65 \%$ was reported in this experimental study.
\end{abstract}

Keywords: photo voltaic module, computational fluid dynamics analysis, solar panel cleaning mechanism.

\section{Nomenclature}

$P_{m} \quad$ Maximum power of the solar panels

$E \quad$ Incident radiation flux

$V_{o c} \quad$ Open circuit voltage

$I_{o c} \quad$ Open circuit current

FF Fill factor

$T_{c} \quad$ Photo Voltic cell temperature $\left({ }^{\circ} \mathrm{C}\right)$

$T_{a} \quad$ Ambient temperature $\left({ }^{\circ} \mathrm{C}\right)$

$T_{C, N O C T} \quad$ Nominal operating cell temperature $\left({ }^{\circ} \mathrm{C}\right)$

$T_{a, N O C T}$ Ambient temperature at which the nominal operating cell. Temperature is defined $\left(20^{\circ} \mathrm{C}\right)$

$G_{T} \quad$ The solar radiation striking the photo voltaic module $\left(\mathrm{KW} / \mathrm{m}^{2}\right)$

$G_{T, N O C T}$ The solar radiation at which the normal operating cell. Temperature is defined $\left(\mathrm{KW} / \mathrm{m}^{2}\right)$

$H_{m p, S T C} \quad$ Maximum power point efficiency under standard test conditions

$\alpha_{p} \quad$ The temperature coefficient of power $\left(\% /{ }^{\circ} \mathrm{C}\right)$

$T_{c, S T C} \quad$ Solar cell temperature under standard test conditions $\left(25^{\circ} \mathrm{C}\right)$

$\tau \quad$ Solar transmittance of any cover over the photo voltaic array (\%)

$\alpha \quad$ Solar absorptance of the photo voltaic module (\%) 


\section{Introduction}

Efficiency of the commercial solar panels is severely limited. This efficiency is further reduced by the external factors such as the accumulation of dust on surface of the solar panel, ambient temperature, orientation of solar panels, temperature of solar cells. This results in the decrease of power output from the solar panels. Solar panels are developed to obtain the maximum possible energy, either through electricity or heat. The power output from the photo voltaic module depends on the incident solar irradiance and spectral content. To obtain the maximum possible current output from the solar panels they need to be cleaned regularly and should be maintained at an optimum temperature. Several methods are developed to deal with these affects.

Hussain et al. [1] studied the effect of dust particles on photo voltaic panels for different dust samples under different radiations and observed that more sunlight is blocked by small particles. Deepak et al. [2] concluded that the solar photo voltaic panels have the ability to generate electricity and heat by absorbing solar energy. The photo voltaic panels are designed in such a way to obtain maximum energy either in form of electricity or heat or any other purpose. Saiden et al. [3] recommended that the solar panel cleaning in a scheduled manner is high importance, otherwise the impact of dust particles is higher. Wet cleaning method is more effective method to clean the accumulation of dust particles from the surface of a solar panel than the dry cleaning method [4]. Zuber et al. [5] came to a conclusion that the performance of the photo voltaic cell enhances remarkably using the water spray cooling system. They also concluded that the water cooling has most impact on the photo voltaic cell operating temperature reduction and improves the electrical performance of the photo voltaic panel. Nizetic et al. [5] experimentally investigated water spray cooling effect on the performance of photo voltaic panel in highest solar irradiation level environment. The experiment concluded that the water spray cooling has considerable effect and the simultaneously cooling both front and back sides of photo voltaic panel was the best case.

Chander et al. [7] experimentally investigated the cell temperature impact on the performance of a mono-crystalline silicon photo voltaic module. They noticed that the temperature coefficient for the fill factor, open circuit voltage and maximum power output was negative, whereas for the short circuit current the temperature coefficient is positive.

The objective of this research paper is to develop a system to clean the surface of solar panel and decrease the temperature of the solar cell and perform thermal analysis on the designed cleaning mechanism.

\section{Description of experimental setup}

A set of four photo voltaic modules $(196 \mathrm{~cm} \times 99 \mathrm{~cm} \times 3.5 \mathrm{~cm})$, each consisting of 72 solar cells, were mounted on top of a cast-iron frame inclined at an $28^{\circ}$ angle. The photo voltaic modules are connected in series. A branched network of poly vinyl chloride pipes and brass nozzle, which are fixed on top end of the solar panels, are used to supply water. The water is drawn out form a storage tank using a A.C. motor. The A.C. motor is operated using a time switch at specific two hour interval between $6 \mathrm{AM}$ and $6 \mathrm{PM}$. The time switch is connected to a solar inverter, which converts the Direct Current from solar panels to Alternating Current. A.C. motor power from the solar panels. The experimental setup is shown below in Fig. 1(a) and Fig. 1(b). The incident solar radiation on the surface of the photo voltaic module is measured using a solarimeter.

\section{Analysis of photo voltaic module system}

The surface area of photo voltaic module is given by:

$A_{c}=w \times l \mathrm{~m}^{2}$.

The maximum efficiency $(\eta)$ of the solar panel module at STC $\left(25^{\circ} \mathrm{C}\right)$ is given by the 
expression:

$\eta=\frac{P_{m}}{E \times A_{c}} \times 100$

here $P_{m}=310 \mathrm{~W}$ and $E=1000 \mathrm{~W} / \mathrm{m}^{2}$, hence $\eta=16.00 \%$.

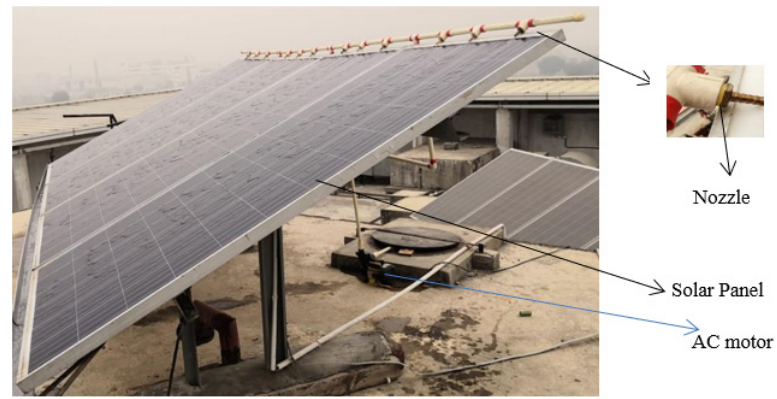

a)

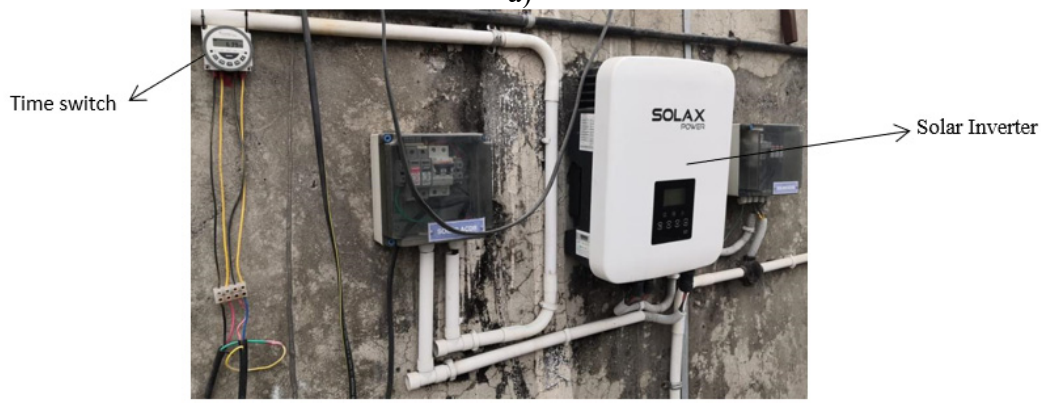

b)

Fig. 1. a) Actual photograph of the experimental setup,

b) image showing the different equipment used in experiment

Table 1. Table showing the specifications of different equipment used in the experiment

\begin{tabular}{|c|c|c|c|}
\hline S. No. & Equipment & No. of items & Specifications \\
\hline 1. & Solar panels & 4 & Panel consist of 72 solar cells \\
\hline 2. & Water tank & 1 & Concrete tank \\
\hline 3. & Pipe & 4 & $\begin{array}{c}\text { Material: Poly Vinyl Chloride; } \\
\text { Diameter: } 3 / 4 \text { inch; Length: } 12 \text { meters }\end{array}$ \\
\hline 4. & AC motor & 1 & V-Guard Nova, 0.5 Horse Power \\
\hline 5. & Elbow joints & 4 & Material: Poly Vinyl Chloride; Diameter: $3 / 4$ inch \\
\hline 6. & T-joints & 14 & Material: Poly Vinyl Chloride; Diameter: $3 / 4$ inch \\
\hline 7. & Nozzle & 12 & Material: Brass; Diameter: $6 \mathrm{~mm}$ \\
\hline 8. & Time switch & 1 & Model: frontier TM619H2 \\
\hline 9. & Solar inverter & 1 & Solex inverter, Capacity: $3 \mathrm{KW}$ \\
\hline 10. & Support stand & 2 & Material: Cast Iron; Length: $153 \mathrm{~cm}$ \\
\hline 11. & Solarimeter & 1 & $\begin{array}{c}\text { Digital solar power meter } \\
\text { Model: KM-SPM-11 }\end{array}$ \\
\hline
\end{tabular}

The Fill factor $(F F)$ of the solar cell is calculated using the following equation:

$F F=\frac{P_{m}}{V_{o c} \times I_{o c}}$,

here $V_{o c}=45.5 \mathrm{~V}$ and $I_{o c}=8.85 \mathrm{~A}$, hence $F F=0.769$. 
The expression for electrical efficiency of the photo voltaic module:

$V_{m}=\frac{V_{o c} \times I_{o c} \times F F}{\text { Solar irradiance } \times A_{c}}$.

The expression for instantaneous efficiency $\eta_{\text {inst }}$ of the module at any temperature $T_{\text {inst }}$ is given by:

$\eta_{\text {inst }}=\eta-\left[\left(T_{\text {inst }}-25\right) *\right.$ Temperature coefficient of $\left.P_{m}\right]$

here, temperature coefficient of $P_{m}=-0.39 \% /{ }^{\circ} \mathrm{C}$.

The expression to calculate the solar cell temperature is as follows:

$T_{c}=\frac{T_{a}+\left(T_{c, N O C T}-T_{a, N O C T}\right)\left(\frac{G_{T}}{G_{T, N O C T}}\right)\left[1-\frac{\eta_{m p, S T C}\left(1-\alpha_{p} T_{c, S T C}\right)}{\tau \alpha}\right]}{1+\left(T_{c, N O C T}-T_{a, N O C T}\right)\left(\frac{G_{T}}{G_{T, N O C T}}\right)\left(\frac{\alpha_{p} \eta_{m p, S T C}}{\tau \alpha}\right)}$.

\section{Results and discussions}

The experimental study has been conducted at Bennett University, Greater Noida and the experimental readings are noted in Table 2. The Eq. (4) and Eq. (5) are used to calculate the electrical efficiency and instantaneous efficiency of the system respectively. The solar cell temperature can be mathematically calculated using Eq. (6).

Table 2. Table showing the experimental readings obtained for ambient and solar cell temperature

\begin{tabular}{|c|c|c|c|}
\hline $\begin{array}{c}\text { Time } \\
(\mathrm{Hrs})\end{array}$ & $\begin{array}{c}\text { Ambient temperature } \\
\left({ }^{\circ} \mathrm{C}\right)\end{array}$ & $\begin{array}{c}\text { Solar cell temperature } \\
\text { before cleaning }\left({ }^{\circ} \mathrm{C}\right)\end{array}$ & $\begin{array}{c}\text { Solar cell temperature } \\
\text { after cleaning }\left({ }^{\circ} \mathrm{C}\right)\end{array}$ \\
\hline $6: 00$ & 20 & 23 & 22.73 \\
\hline $8: 00$ & 23 & 33.9 & 31.6 \\
\hline $10: 00$ & 28 & 44 & 40.81 \\
\hline $12: 00$ & 33 & 51 & 47.3 \\
\hline $14: 00$ & 34 & 49 & 46.5 \\
\hline $16: 00$ & 32 & 38 & 37.59 \\
\hline $18: 00$ & 29 & 32 & 31.6 \\
\hline
\end{tabular}

A photo voltaic panel was designed and analyzed in ANSYS Fluids R19.1 (mechanical). The symmetric section of photo voltaic panel has dimensions of $49 \mathrm{~cm} \times 99 \mathrm{~cm} \times 3.5 \mathrm{~cm}$ as shown in Fig. 2. The silicon layer in photo voltaic module is sandwiched between two glass layers. The geometry is then meshed (volume mesh) as shown in Fig. 3. The results obtained in the thermal analysis are noted in Table 3.

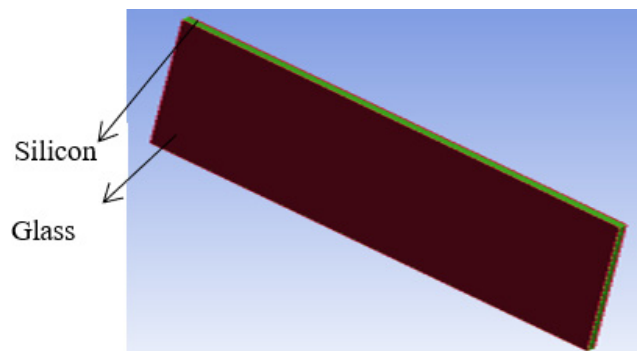

Fig. 2. Geometry of single photo voltaic module

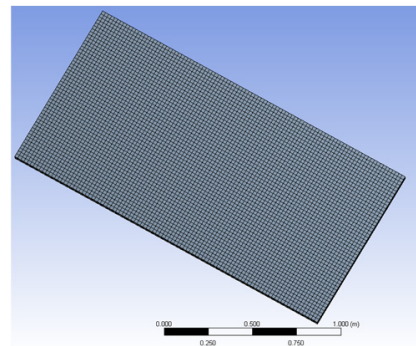

Fig. 3. Meshing of single photo voltaic module 
Table 3. Table showing the reading obtained in thermal analysis

\begin{tabular}{|c|c|c|}
\hline $\begin{array}{c}\text { Ambient temperature } \\
\left({ }^{\circ} \mathrm{C}\right)\end{array}$ & $\begin{array}{c}\text { Solar cell temperature before } \\
\text { cleaning }\left({ }^{\circ} \mathrm{C}\right)\end{array}$ & $\begin{array}{c}\text { Solar cell temperature obtained in } \\
\text { analysis }\left({ }^{\circ} \mathrm{C}\right)\end{array}$ \\
\hline 20 & 23 & 22.187 \\
\hline 23 & 33.9 & 30.945 \\
\hline 28 & 44 & 39.662 \\
\hline 33 & 51 & 46.12 \\
\hline 34 & 49 & 44.933 \\
\hline 32 & 38 & 36.373 \\
\hline 29 & 32 & 31.187 \\
\hline
\end{tabular}

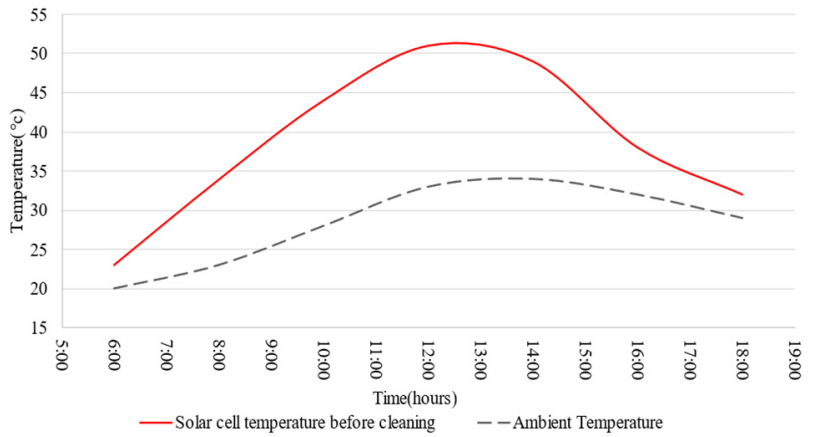

Fig. 4. Variation of ambient temperature and Solar cell temperature with respect to time

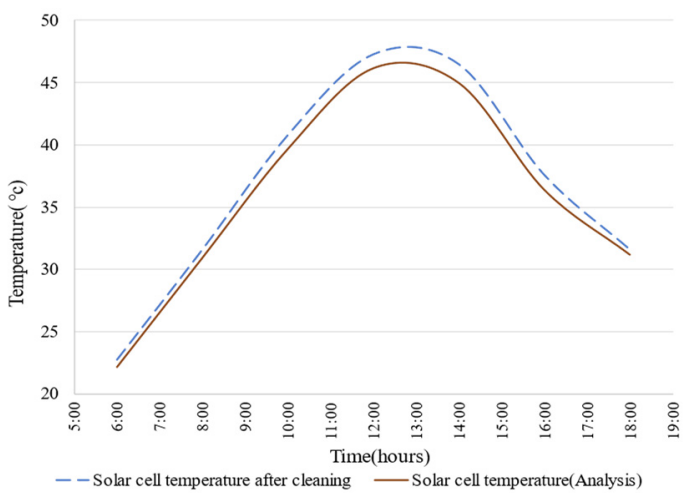

Fig. 5. Variation of experimental and analytical solar cell temperature with respect to time

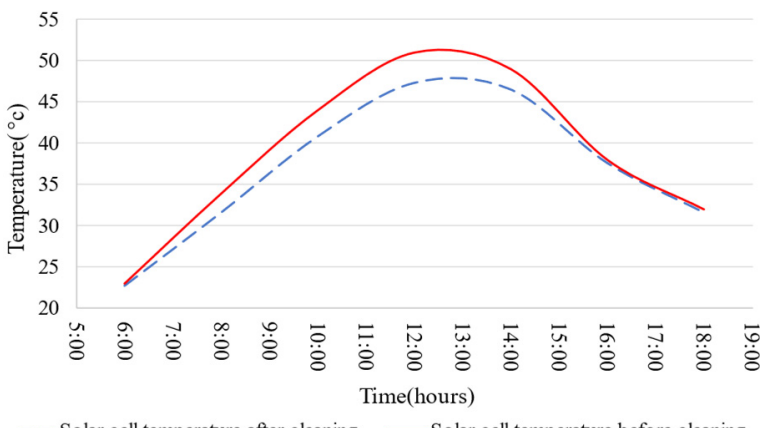

-- Solar cell temperature after cleaning - Solar cell temperature before cleaning
Fig. 6. Variation of solar cell temperature with respect to time

The plot for the variation of ambient temperature and the solar cell temperature before cleaning with respect to the time is shown in the Fig. 4, The plot in Fig. 6, shows the variation of solar cell 
temperature before and after cleaning with respect to time. Variation of solar cell temperature obtained after cleaning the photo voltaic module and the temperatures obtained in the thermal analysis are shown in Fig. 5. The solar cell temperature initially increases and then decreases during a day.

\section{Conclusions}

The following conclusions are derived from the experimental study and the thermal analysis performed on the designed experimental system.

1) The solar cell temperature increases as the ambient temperature increases day.

2) The Solar cell temperature was found to be maximum between 12 PM and 2 PM during the

3) Increase in the efficiency of the solar panel after implementing the cleaning mechanism was observed to be maximum during $12 \mathrm{PM}$ and $3 \mathrm{PM}$.

4) The heat exchange on the surface of solar panel was observed to be higher between $10 \mathrm{AM}$ and $2 \mathrm{PM}$.

5) This mechanism increases the efficiency of the solar panels economically and requires less effort. The efficiency of solar panels was found to increase by $1.28 \%$ to $2.65 \%$.

\section{References}

[1] Hussain Athar, Batra Ankit, Pachauri Rupendra An experimental study on effect of dust on power loss in solar photo voltaic module. Renewables, Vol. 4, 2017, p. 9.

[2] Deepak Tiwari, Ahmad Faizan Shaerwani, Deepali Atheaya, Anil Kumar, Nishant Kumar Thermodynamic analysis of organic Rankine cycle driven by reversed absorber hybrid photo voltaic thermal compound parabolic concentrator system. Renewable Energy, Vol. 147, Issue 1, 2020, p. $2118-2127$.

[3] Saidan Motasem, Albaali Abdul Ghani, Alasis Emil, Kaldellis John K. Experimental study on the effect of dust deposition on solar photo voltaic panels in desert environment. Renewable Energy, Vol. 92, 2016, p. 499-505.

[4] Kiran M. R., Padaki Rekha G. Self-cleaning technology for solar PV panels. International Journal of Scientific Development and Research, Vol. 1, Issue 9, 2016, p. 148-173.

[5] Zubeer A., Mohammed H. A., Mustafa Ilkan A review of photo voltaic cells cooling techniques. E3S Web of Conferences, 2017.

[6] Nizetic S., Coko D., Yadav A., Grubisi-Cabo F. Water spray cooling technique applied on a photo voltaic panel: The performance response. Energy Conversion and Management, Vol. 108, 2016, p. 287-296.

[7] Chander S., Purohit A., Sharma A., Arvind S. P., Nehra M. S., Dhaka M. S. Impact of temperature on performance of series and parallel connected mono-crystalline silicon solar cells. Energy Reports, Vol. 1, 2015, p. 175-180. 